\title{
MUZEUM I NOWE MEDIA. ROZWÓJ OFERTY CYFROWEJ W CZASIE PANDEMII
}

\author{
Abstract \\ MUSEUM AND NEW MEDIA. DEVELOPMENT OF THE DIGITAL OFFER \\ IN THE TIME OF THE PANDEMIC
}

This article outlines the results of studies analysing the activity of museums around the world during the period of limited cultural activity caused by the COVID-19 pandemic. Because of these unprecedented circumstances, virtually all activities of museums have been transferred to the digital reality of the Internet and premised on the functionalities offered by the new media. Even though the existence of relationships between museums and the media is not a new development, its intensity during the pandemic reached unprecedented levels. Furthermore, during the pandemic, there emerged new types of services offered by museums, and they will likely remain a permanent fixture of their offer. Notably, such a broadened offer significantly increases the educational potential of museums and directly relates to the demand for lifelong learning.

Keywords: museum, new media, digital culture, digital museum

\section{Wprowadzenie}

Związki muzeów z mediami są oczywiste i naturalne. Instytucje posiadające nawet najlepsze zbiory, oferujące zwiedzającym doskonałe galerie i wystawy czasowe, nie są w stanie funkcjonować na rynku zarządzania czasem wolnym bez wsparcia mediów: nie tylko na bieżąco komentują one muzealne życie, ale są również źródłem różnorakich informacji praktycznych przeznaczonych dla zwiedzających. Od momentu rozwoju mediów elektronicznych media na stałe wpisały się już nie tylko w otoczenie społeczne muzeum, w którym dotychczas postrzegane były jako jeden $\mathrm{z}$ istotnych interesariuszy, ale wrosły na stałe $\mathrm{w}$ strukturę organizacji. To z tego 
powodu w wydanej ponad dekadę temu książce Museum Marketing and Strategy będącej efektem współpracy rodzinnej jednego z najwybitniejszych znawców marketingu Philipa Kotlera - autorzy tak pisali o roli mediów w muzeach: „Digital media have been a part of museum for a number of years, but their growth and role in museums has accelerated. Media today are integral to museums and museums exhibition" (Kotler, 2008, s. 16). Najważniejszą zmianę w tym obszarze przyniosły media elektroniczne, które dokonały de facto zmiany w modelu komunikacji, jaki wcześniej obowiązywał w muzeach, w odniesieniu do otoczenia społecznego. Nadejście tej zmiany przewidywali badacze, zajmując się problematyką zarządzania mediami. Tak pisał o niej na przykład Bogusław Nierenberg:

(...) współczesny człowiek za sprawą Internetu i elektronicznych środków komunikowania jest w stanie konstruować własne przekazy, dla niego najbardziej satysfakcjonujące. Oto obok powszechnego procesu wymiany mamy powrót do „produkcji na własne potrzeby”. Jakie będą konsekwencje tego zjawiska? Trudno orzec, ale bez wątpienia ma ono duży wpływ, i będzie miało coraz większy, na stosunki społeczne, sposób uprawiania polityki, a przede wszystkim na rynek medialny i oferowane na nim dobra (Nierenberg, 2011, s. 89$)$.

Jak się okazało, miało to również istotny wpływ na budowanie relacji z otoczeniem przez muzea. $Z$ perspektywy niniejszego artykułu kluczowa jest zmiana perspektywy badania muzeów - należy spojrzeć na muzea nie tylko jak na instytucję sektora kultury, ale jak na podmiot wchodzący w rynek mediów, nie tylko jako klient, lecz także jako wytwórca. Tę konieczność zmiany recepcji i badania muzeów można wywieść z klasycznego tekstu Roberta G. Picarda stwierdzającego przed laty, że „(...) ekonomika mediów analizuje sposoby, jakimi podmioty posługujące się mediami zaspokajają informacyjne i rozrywkowe potrzeby oraz oczekiwania audytoriów, reklamodawców, a także społeczeństwa jako całości w ramach dostępnych im zasobów; zajmuje się czynnikami wpływającymi na produkcję dóbr i usług medialnych oraz alokację tych produktów wśród konsumentów" (Picard, 1989, s. 7). Kwestią do rozstrzygnięcia w najbliższych latach pozostanie, na ile ta postępująca zmiana w technologiach komunikacyjnych pozwoli traktować muzea (a w każdym razie największe $\mathrm{z}$ nich) jako istotne podmioty posługujące się mediami (media operators).

Prezentowany artykuł ma charakter przeglądowy, odnosi się do najnowszych zjawisk związanych $\mathrm{z}$ funkcjonowaniem mediów w muzeach. Zgodnie z założeniem, ma wypełniać lukę w spojrzeniu na sektor mediów, zmuszając do recepcji muzeum jako podmiotu posługującego się mediami. Ważnym pytaniem pozostaje, na ile muzea są pomiotem korzystającym z mediów, a na ile w ostatnich latach stały się już pełnoprawnym „producentem” treści, generatorem sektora kreatywnego. Podstawową metodą badawczą wykorzystaną w artykule jest studium przypadku. 


\section{Teoria i praktyka cyfryzacji w muzeach}

Kotlerowie, pisząc przed kilkunasty laty swoją opinię na temat związków muzeów z mediami, najprawdopodobniej nie byli w stanie przewidzieć, jak dalece prawdziwy jest ich sąd oraz jak głęboko media cyfrowe będą wrastać w tkankę muzeów. Nic w tym dziwnego - choć wszyscy zdajemy sobie sprawę z błyskawicznej ekspansji technologii cyfrowych, niejednokrotnie tempo tego postępu bywa zaskakujące. Wystarczy sięgnąć do najnowszego raportu poświęconego mediom społecznościowym Digital 2020, opublikowanego przez serwis We Are Social (2020) we współpracy z Hootsuite. Zgodnie z zawartymi tam danymi w skali globalnej w styczniu 2020 roku z Internetu korzystało na świecie 59\% populacji, w Polsce zaś - 81\%. Aktywni użytkownicy mediów społecznościowych stanowili 49\% mieszkańców naszej planety, w Polsce - 50\%. Jeśli weźmiemy pod uwagę roczny wzrost użytkowników mediów społecznościowych (na świecie każdego roku było to 7\%, w Polsce między kwietniem 2019 roku a styczniem 2020 roku - 7,8\%), uświadomimy sobie, jak wielki potencjał drzemie w tym obszarze. Naiwnością byłoby zakładać, że muzea czy instytucje kultury w ogóle - podlegają innym prawom w tym zakresie. O tym, jak bardzo media „wrosły” w muzea (albo szerzej: w sektor kultury), uświadamiają prowadzone w tym obszarze badania. Respondenci bodaj najszerzej zakrojonego w Polsce badania Krakowski odbiorca kultury (ponad 2600 osób poddanych badaniu) na pytanie: „Gdzie zetknął się Pan / zetknęła się Pani z informacją o (...) wydarzeniu?", w ponad 50\% jako źródło pozyskiwania informacji na temat oferty kulturalnej wskazywało szeroko pojęty Internet. „Najwięcej ankietowanych (33,2\%) korzysta $\mathrm{z}$ informacji o wydarzeniu zamieszczonej na stronie internetowej instytucji, 11,6\% korzysta z mediów społecznościowych instytucji (z czego 98,2\% podało Facebook), a 10,5\% z innych stron internetowych" (Gaweł et. al., 2019, s. 27).

$\mathrm{W}$ muzeach „(...) daje się zauważyć coraz powszechniejsze wykorzystanie Internetu, już nie tylko dla promocji muzeum i umieszczenia informacji o godzinach otwarcia, lecz również dla przedstawienia części kolekcji lub informacji tę kolekcję wzbogacających. Kolekcje cyfrowe pozwalają na tworzenie wystaw obiektów muzealnych, które spoczywają w archiwach, magazynach lub są wypożyczone" (Wiza, 2010, s. 89). W przytoczonym fragmencie pojawiają się dwa istotne wątki w kontekście poruszanego tematu. Sprawa pierwsza to wykorzystywanie mediów cyfrowych do przekazywania informacji związanych $\mathrm{z}$ wystawami (stałymi i zmiennymi), stanowiących uzupełnienie treści prezentowanych na ekspozycji, dających możliwość poszerzania wiedzy nie tylko podczas zwiedzania muzeum, ale właściwie $\mathrm{w}$ dowolnym czasie. Tym sposobem media cyfrowe zapewniają praktycznie stały dostęp do wiedzy. Drugą sprawą jest kwestia zwiększania zasobu cyfrowego samych muzeów. Realizowane w wielu placówkach projekty digitalizacyjne powodują systematyczny i dość szybki przyrost reprodukcji cyfrowych muzealiów, do których zapewniany jest coraz szerszy i łatwiejszy dostęp. Dzięki szerokopasmowemu Internetowi specjalnej platformy oferują zarówno dostęp do reprodukcji cyfrowych, 
nierzadko w wysokich rozdzielczościach, jak również do wielu metadanych znacząco poszerzających możliwości wykorzystania tych materiałów. Dobrym przykładem mogą tu być platformy stworzone w największych polskich muzeach, miedzy innymi w Muzeum Narodowym w Warszawie (www.cyfrowe.mnw.art.pl) czy Muzeum Narodowym w Krakowie (www.zbiory.mnk.pl).

Prawdziwą rewolucję medialną w świecie muzeów przyniosły jednak możliwości, jakie stworzył Internet 2.0. Zmiana w obszarze komunikacji - z jednokierunkowej do dwukierunkowej - sytuacja, w której dotychczasowi odbiorcy treści mogli się stać również ich twórcami, doskonale określa przemianę, jaką w ponowoczesnym świecie przechodzą muzea jako takie. Zmiana ta bywa opisywana jako przejście od stylu autorytarnego do demokratycznego (Piontek, 2016, s. 231). W pierwszym typie muzeum przyjmuje rolę niepodważalnego autorytetu, charakteryzuje się podejściem hierarchicznym i odpowiadającą mu komunikacją „z góry” (muzeum pouczające) „do dołu” (widzowie są odbiorcami instrukcji, poleceń czy nakazów). Styl autorytarny jest $\mathrm{w}$ istocie monologiem; w stylu demokratycznym obowiązującą formą komunikacji jest dialog, wymiana myśli, dyskusja na temat przedstawionych treści, wartości czy interpretacji. W naturalny sposób wszystkie warunki komunikacji demokratycznej w muzeum partycypacyjnym spełniają współczesne media cyfrowe. Graham Black uważa tę zmianę za najważniejszą dla współczesności i przyszłości muzeów:

The ambition for the twenty-first century museum should be to change the mind-set of museum audiences, converting them from one-off visitors into regular users who see themselves as active partners in the work of the museum. For this to happen, we must begin by learning much more about current and potential users and responding to what this reveals. But museums must also transform themselves in both attitude and practice. This cannot wait (Black, 2012, s. 15).

Opisywana przez Blacka konieczna przemiana muzeów nie dokona się bez udziału mediów cyfrowych. To kolejny obszar ich znaczenia dla współczesnych instytucji kultury. Powszechnie panuje opinia o anonimowości Internetu, tymczasem odpowiednio zaprojektowana komunikacja z odbiorcami może dostarczać na ich temat wielu cennych informacji - w tym ujęciu nowe media stają się dla muzeów nieodzownym narzędziem diagnozy, środkiem do lepszego poznania swoich odbiorców.

Wszystko, co napisano powyżej, jest zarysem zagadnienia obecności i znaczenia nowych mediów dla muzeów. Nikt nie był jednak w stanie przewidzieć, jakie zmiany w tym zakresie przyniesie panująca na świecie w 2020 roku pandemia nowej choroby COVID-19, która wymusiła zamknięcie dla publiczności muzeów na całym świecie. Chcąc zachować w nowej rzeczywistości kontakt z odbiorcami, muzea sięgnęły do technologii cyfrowych, szczególnie do nowych mediów. 


\section{Metodologia}

Badanie stanowiące podstawę niniejszego artykułu prowadzono między 12 marca a 12 maja 2020 roku. Był to czas, w jakim ze względu na pandemię koronawirusa Muzeum Narodowe w Warszawie (podobnie jak inne muzea w naszym kraju) zostało zamknięte dla odwiedzających. Szukając nowych form aktywności, a także sposobów na zachowanie kontaktu z odbiorcami, Dział Edukacji Muzeum Narodowego w Warszawie prowadził stały monitoring wybranych muzeów na świecie. Własne badanie tego obszaru prowadził autor artykułu. Polegało ono na codziennym monitorowaniu aktywności wybranych instytucji celem obserwowania działania konkurencji z jednaj strony, z drugiej zaś - poszukiwania inspiracji dla własnych działań. Łącznie badaniem objęto sześćdziesiąt pięć muzeów, głównie z Europy (w tym polskich), ale również ze Stanów Zjednoczonych, Kanady oraz Australii. Wybór obserwowanych muzeów podyktowany był ich renomą, znaczeniem kolekcji, a także dotychczasową aktywnością w Internecie.

\section{Muzea w czasach zarazy}

Na wstępie należy zaznaczyć, że w świecie muzeów wykształcił się pewien standard, jeśli chodzi o wykorzystywanie mediów cyfrowych. Normą jest posiadanie własnej strony internetowej, a ponadto korzystanie z Facebooka, Twittera, Instagrama oraz kanału na YouTube. Osobną sprawą pozostaje stopień aktywności w opisanych obszarach - należy jednak podkreślić, że w momencie zamknięcia muzeów z powodu pandemii, wykorzystywano praktycznie wszystkie wymienione kanały informacji.

Analiza treści zamieszczanych przez muzea w momencie ogłoszenia ich zamknięcia $\mathrm{z}$ powodu pandemii uświadamia, jak różna była $\mathrm{w}$ tych instytucjach świadomość potencjału tkwiącego w nowych mediach. Sama decyzja o zamknięciu muzeów, którą należy uznać za bezprecedensową ze względu na skalę i zasięg, była dla zarządzających olbrzymim zaskoczeniem. W początkowym okresie wszystkie badane muzea skupiły się przede wszystkim na poinformowaniu zwiedzających o zamknięciu galerii i ekspozycji. W pierwszych dniach nierzadko były to jedynie lakoniczne informacje na temat zamknięcia instytucji. W kanałach informacyjnych w dziewiętnastu spośród badanych muzeów pojawiły się informacje dotyczące możliwości uzyskania zwrotu środków za zakupione bilety (zarówno na wystawy, jak i na inne wydarzenia organizowane przez instytucje). W dwóch przypadkach (londyńskim Tate oraz Ashmolean Museum w Oksfordzie) zwrócono się do odwiedzających, aby rozważyli potraktowanie tych wpłat jako darowizny na rzecz muzeum. Niektóre muzea podeszły jednak do sprawy inaczej, doskonale zdając sobie sprawę, że nawet kryzysowa sytuacja może być wykorzystana do kreowania pożądanego wizerunku organizacji. Można wskazać w tym zakresie kilka strategii działania. 
Niektóre muzea informowały przede wszystkim o bezpieczeństwie zespołu, zapewniając, że otrzymał on odpowiednie wsparcie (The National Gallery, Londyn; The J. Paul Getty Museum, Los Angeles). Inne podkreślały swoją odpowiedzialność za otoczenie społeczne (bezpieczeństwo zwiedzających, nierozprzestrzenianie wirusa), tłumacząc tym decyzję o zamknięciu ekspozycji dla odwiedzających (między innymi muzea nowojorskie: Museum of Modern Art oraz Whitney Museum of American Art). Szczególny w tym zakresie był komunikat z Getty Museum, informującego, że instytucja przekazała partię rękawiczek i masek do jednego z centrów medycznych. Zupełnie wyjątkowa była akcja przeprowadzona przez Muzeum Powstania Warszawskiego. Korzystając z mediów społecznościowych, muzeum zwróciło się do swoich widzów, aby zasilili zespół wolontariuszy celem przeprowadzenia akcji „Zadzwoń do dziadka”. Muzeum postanowiło objąć opieką dawnych powstańców warszawskich, osoby w podeszłym wieku, dla których czas pandemii pod wieloma względami jest szczególnie trudnym doświadczeniem.

Sześć muzeów od samego początku bardzo świadomie korzystało z mediów społecznościowych w celu budowania spersonalizowanego kontaktu między odbiorcami a instytucją reprezentowaną przez dyrektora. W tej grupie wyróżniał się między innymi osobisty w tonie list dyrektorki Dulwich Picture Gallery w Londynie Jennifer Scott skierowany do społeczności skupionej wokół instytucji. Również dyrektor Royal Ontario Museum w Toronto zwrócił się do „muzealnej rodziny”. Nie tylko zachęcał on do zapoznania się z kolekcją cyfrową muzeum, ale także podkreślał znaczenie kultury w trudnym czasie.

Zmianę skali wykorzystania mediów społecznościowych przez muzea przynosi drugi okres zamknięcia tych instytucji dla zwiedzających. Trudno wskazać jednoznaczną datę, wspólną dla wszystkich muzeów, ale kilka tygodni po zamknięciu muzeów dla zwiedzających stało się jasne, że nie jest to decyzja chwilowa, a stan ten może trwać bardzo długo. Muzea zaczęły więc szukać nowego rodzaju oferty (kontentu), która byłaby dostępna dla dotychczasowych zwiedzających z domu, przez Internet. Najpopularniejszą formą dostępu do zbioru były różnego rodzaju galerie cyfrowe, czyli udostępnienie zwiedzającym jak najłatwiejszego dostępu do zasobów cyfrowych instytucji. Należy przy tym podkreślić, że nie były to inicjatywy nowe (żadne muzeum nie byłoby w stanie w tak krótkim czasie zbudować nowej platformy cyfrowej) - chodziło raczej o szeroką promocję tych platform oraz ewentualnie opracowanie nowych form korzystania z nich. Warto jednak w tym miejscu wskazać różnice w potencjale muzeów pod względem pozostających do ich dyspozycji zasobów finansowych. Całkowitej rewolucji dokonało na przykład The Metropolitan Museum of Art w Nowym Jorku, prezentując pod koniec marca zupełnie nową stronę internetową, zaprojektowaną w całości pod kątem funkcjonowania muzeum w trybie online.

Ciekawy sposób korzystania ze swoich zasobów cyfrowych zaproponowało Los Angeles County Museum of Art (LACMA), wprowadzając kategorie ułatwiające odbiorcom nawigowanie po bogatej kolekcji (watch, listen, learn, read, browse 
at home). Ciekawy sposób na prezentację zbiorów został zaproponowany również $\mathrm{w}$ Royal Collection Trust z Londynu - udostępniono trzy tysiące map z czasów Jerzego III wraz z odnośnikami do współczesnych map Google. Kilka muzeów wykorzystało dostępne media w nowatorski sposób, prezentując w nich materiały audiowizualne ze swoich kolekcji - można zaryzykować stwierdzenie, że dzięki pandemii te dzieła sztuki zyskały pełnię wyrazu w szerokim dostępie dla odbiorców. Na przykład od połowy kwietnia nową akcję w tym zakresie rozpoczęło Whitney Museum of American Art w Nowym Jorku. Pod wspólnym tytułem Whitney Screens w każdy piątek po południu prezentowano nowe nabytki dzieł z nurtu videoartu (z wykorzystaniem platformy Vimeo).

Należy podkreślić, że to właśnie wypracowane wcześniej zasoby cyfrowe muzeów stały się podstawą nowej oferty. Dobrej jakości zdjęcia obiektów były bowiem wykorzystywane $\mathrm{w}$ różnego rodzaju materiałach produkowanych przez muzea podczas lockdownu. W licznych muzeach - w ramach różnego rodzaju cykli - powstały materiały audiowizualne, w których kuratorzy opowiadali o ulubionych dziełach czy najwybitniejszych artefaktach z kolekcji. Konwencja tych materiałów była bardzo różnorodna - od profesjonalnych (czy półprofesjonalnych) produkcji tworzonych przez zespół na terenie muzeum po amatorskie materiały kręcone przez samych kuratorów we własnych domach (takie materiały udostępniało na przykład Rijksmuseum z Amsterdamu). Wraz z upływem czasu rosła liczba materiałów z udziałem kuratorów, edukatorów i konserwatorów, zwiększała się również liczba odmian tego typu kontentu. Oprócz wymienionych wcześniej pojawiły się materiały edukacyjne na różne tematy, opowieści o konserwacji poszczególnych dzieł sztuki czy też wykłady kuratorskie na wybrane zagadnienia; osobną formułą były spotkania z kuratorami. Za nowatorską i nietypową akcję wypada uznać przygotowaną przez Los Angeles County Museum of Art ofertę kursów online dostępnych bezpłatnie na stronie internetowej instytucji (można było między innymi zdobyć wiedzę w ramach kursów Malarstwo chińskie, Obrazy wojny, Sztuka i sprawiedliwość). Poszerzono również wykorzystywaną jeszcze przed pandemią formułę oprowadzania live przez kuratora. Streamingi za pośrednictwem mediów społecznościowych miały tworzyć namiastkę oprowadzania kuratorskiego po wystawie. Specyficzną odmianą tej formuły była możliwość zwiedzania wystawy z dyrektorem - taką atrakcję przygotował między innymi Zamek Królewski w Warszawie, którego „cyfrowi” goście mogli zwiedzić ekspozycję z profesorem Wojciechem Fałkowskim. Możliwość zwiedzania online zaproponowały również te muzea, które na czas pandemii miały przewidziane otwarcie nowych wystaw zmiennych. Wysiłek włożony w przygotowanie tego typu ekspozycji oraz czas im poświęcony skłoniły niektóre muzea do tego, aby nie tracić wypracowanego efektu oraz - przede wszystkim - zaangażowania ludzkiego i finansowego. Na przykład National Gallery of Art w Waszyngtonie przeniosła do sieci wystawy czasowe, prezentując zdjęcia oraz teksty, wiedeńska Albertina dodatkowo zaś wprowadziła nagrania audio poświęcone poszczególnym obiektom. Nieco inną formułę wypracowało Muzeum 
Narodowe we Wrocławiu, prezentując krótkie filmy skomponowane ze zdjęć wykonanych na wystawach czasowych.

Wraz z płynącym czasem rosła nie tylko liczba, ale również jakość przygotowywanych materiałów online. Przykładem może być nagrodzony Marką Radia Kraków za marzec 2020 roku cykl filmów \#przezdziurkęodklucza wyprodukowanych przez Zamek Królewski na Wawelu. Jak możemy przeczytać na stronie internetowej muzeum: „Będziemy w krótkich filmikach pokazywać, co dzieje się w muzeum, jakie prace trwają w wawelskich ogrodach, o zbiorach opowiedzą nasi kustosze. Razem z nami przejdziecie przez zamknięte komnaty zamku. W ten sposób Wawel pozostaje dla Was otwarty" (Zamek Królewski na Wawelu, 2020). Jednocześnie w mediach społecznościowych rosła liczba hasztagów, którymi znaczono kolejne akcje generowane przez muzea na całym świecie, na przykład: \#apaintingaday (Mauritshuis w Hadze), \#CasaCarrara (Accademia Carrara w Bergamo), \#IsolationCreations (Ashmolean Museum, Oxford), \#MetAnywhere (Metropolitan Museum of Art w Nowym Jorku), \#niebawemwmnw (Muzeum Narodowe w Warszawie), \#rijksmuseumfromhome (Rijksmuseum w Amsterdamie), \#StayAtHomeStedelijk (Stedelijk Museum w Amsterdamie), \#UffiziDecameron (Galleria degli Uffizi we Florencji), \#WirtualneŁazienki (Muzeum Łazienki Królewskie w Warszawie).

Kryły się pod nimi najróżniejsze inicjatywy. Muzea dzięki nowym mediom zapraszały do korzystania z katalogów online, wysłuchania wykładów, poznawania tajemnic kolekcji, prezentowały nieznane obiekty. Wiele instytucji wprowadziło do sieci audioprzewodniki. Nowatorskie działania w zakresie wykorzystania nowych mediów przeprowadziła warszawska Zachęta - chodzi o akcję „Zachęta miga!” czy też „Sztuka dostępna”, poświęcone zwiększeniu dostępu do kolekcji dla osób z niepełnosprawnościami (w tym przypadku osób niewidomych oraz głuchoniemych materiały opatrzono tłumaczeniem na polski język migowy oraz warstwą audiodeskrypcji).

Jest jeszcze jeden aspekt wart omówienia w kontekście wykorzystania przez muzea mediów cyfrowych. Jak powszechnie wiadomo, ich siła polega na możliwości dzielenia się treścią, wzajemnych inspiracji. Nie inaczej stało się w przypadku omawianych instytucji. Wzajemnie się inspirując, „podglądając” ofertę konkurencji, muzea wprowadzały w przestrzeń Internetu coraz to nowe treści i funkcjonalności. Chyba najlepszym przykładem inspirowania się swoimi działaniami jest zachęcanie odbiorców do kreatywnej aktywności, której podstawą miały być reprodukcje cyfrowe dzieł. Największy rozgłos zyskało bodaj Getty Museum, zachęcające do wykonywania zdjęć inspirowanych ulubionymi dziełami sztuki; w aranżacji miały być wykorzystane przedmioty posiadane $\mathrm{w}$ domu. W ten sposób powstały niezwykłe nowe wersje dzieł Gustava Klimta, Leonarda da Vinci czy Johannesa Vermeera. Polskim odpowiednikiem stała się akcja przeprowadzona przez Muzeum Narodowe w Warszawie. Uzyskany efekt przerósł najśmielsze oczekiwania, a wśród najwyżej ocenianych przez internautów przeróbek znalazła się Pomarańczarka 
z papierem toaletowym zamiast owoców (co miało być komentarzem do braku tego materiału higienicznego na wielu rynkach na początku pandemii).

Osobny akapit wypada poświęcić działalności edukacyjnej muzeów - skala i różnorodność powstających materiałów nie miała precedensu w przeszłości. Edukatorzy, kustosze, konserwatorzy opowiadali o zbiorach, pojedynczych dziełach, zjawiskach w historii sztuki czy tajnikach zachowania kolekcji. Przygotowywano materiały kierowane do ściśle określonych grup odbiorców, zachęcano do wspólnego rysowania, opracowywano gry, dystrybuowano materiały mogące być wsparciem dla nauczycieli. Do największych zaskoczeń tego obszaru działalności muzeum online stały się lekcje muzealne przygotowane przez Dział Edukacji Muzeum Narodowego w Warszawie. Lekcje muzealne są standardową ofertą bodaj wszystkich muzeów na świecie. Warszawscy edukatorzy wpadli jednak na pomysł, żeby zrobić je w formie interaktywnej, opartej na kontakcie z odbiorcami w czasie rzeczywistym. Pierwsze zaskoczenie pojawiło się, kiedy taką wirtualną lekcję zamówiła szkoła z Gliwic. Dotychczas z oferty Muzeum Narodowego w Warszawie korzystały przede wszystkim szkoły warszawskie oraz te z najbliższej okolicy. Dostęp do cyfrowego Muzeum pozwolił jednak przełamać te granice. Kolejne lekcje zamawiały szkoły z nierzadko odległych od Warszawy miejscowości, aż w końcu współpracę z muzeum rozpoczęła szkoła polonijna z Australii.

Na przykładzie tego muzeum można zrozumieć skalę wykorzystania mediów cyfrowych w czasie pandemii. Muzeum Narodowe w Warszawie w ciągu dwóch miesięcy zorganizowało 552 lekcje oraz wydarzenia online, w których wzięło udział 10201 osób. Poza tym na stronie internetowej muzeum umieszczono 39 unikatowych wydarzeń (takich jak warsztaty rodzinne czy wieczory w muzeum). Zamieszczane na Facebooku oraz na kanale YouTube filmy miały łącznie 238600 wyświetleń. Strona internetowa miała w tym czasie ponad 430000 odsłon.

\section{Podsumowanie}

Przedstawione wyżej dane każą zweryfikować pogląd na temat znaczenia nowych mediów w muzeach. Choć obecne od lat, w czasie pandemii rozkwitły w sposób niespodziewany, oferując użytkownikom domowym kontakt z muzeum niedostępnym w przestrzeni realnej. Ten trudny czas pokazał jeszcze dwie rzeczy. Po pierwsze, muzea nie tylko wykorzystują nowe media w swojej działalności, ale bardzo często są siłą kreacyjną w tym obszarze, można więc zaryzykować twierdzenie biorąc pod uwagę różnorodność form, treści i wykorzystywanych kanałów komunikacyjnych - że muzea są swoistymi generatorami sektora kreatywnego. Po drugie, współczesne muzea nie mogą zawrócić z raz obranej drogi - nowe media wrosły na stałe w ich strukturę i najprawdopodobniej - również po całkowitym wygaszeniu pandemii - będą pozostawały w stałej ofercie tego typu instytucji. $\mathrm{Na}$ pewno tak się stanie z opisanymi wcześniej interaktywnymi lekcjami muzealnymi 
przygotowywanymi przez Muzeum Narodowe w Warszawie. Nie jest to bowiem korzyść jednostronna. Nie tylko odległe geograficznie szkoły zyskały dostęp do zasobów tego muzeum, ale także Muzeum znalazło prostą drogę, aby budować środowisko swoich ambasadorów, nawet w najodleglejszych zakątkach świata.

\section{Bibliografia}

Black G. (2012). Transforming Museums in the Twenty-First Century. New York: Routledge.

Gaweł Ł., Skowron F., Szostak A. (red.) (2019). Raport z projektu badawczego „Krakowski odbiorca kultury". Kraków: Attyka.

Kotler N.G, Kotler Ph., Kotler W.I. (2008). Museum Marketing and Strategy: Designing Missions, Building Audiences, Generating Revenue and Resources. San Francisco: Jossey-Bass.

Nierenberg B. (2011). Zarządzanie mediami. Ujęcie systemowe. Kraków: Wydawnictwo Uniwersytetu Jagiellońskiego.

Picard R.G. (1989). Media Economics: Concepts and Issues. London: Sage Publications.

Piontek A. (2016). Museum und Partizipation. Theorie und Praxis kooperativer Ausstellungsprojekte und Beteiligungsangebote. Bielefeld: Transcript Verlag.

We Are Social (2020). Digital 2020. July Global Statshot Report. Pobrane z: https://www.slideshare.net/DataReportal/digital-2020-poland-january-2020-v01?fbclid= IwAR2UgTiM7SN 2bZRYxi0DGrFeozDvhrHRr5rAnvkC4lkMPVI7CCMztvkLsl8 (dostęp: 21.07.2020).

Wiza W.R. (2010). Nowe technologie informacyjne w muzeach. W: D. Folga-Januszewska, B. Gutowski (red.), Ekonomia muzeum. Kraków: Universitas.

Zamek Królewski na Wawelu (2020). \#przezdziurkęodklucza. Pobrane z: https://wawel.krakow.pl/przezdziurkeodklucza (dostęp: 20.07.2020). 